\title{
Review
}

\section{ELECTRICAL PROPERTIES OF HYDRATED VANADIUM COMPOUNDS}

\author{
V. Bondarenka and A. Pašiškevičius \\ Semiconductor Physics Institute, A. Goštauto 11, LT-01108 Vilnius, Lithuania \\ E-mail: bond@pfi.lt
}

Received 15 June 2006

\begin{abstract}
Vanadium pentoxide gels have a layered structure, where $\mathrm{V}-\mathrm{O}$ ribbons are separated by water that permit to intercalate a wide range of various ionic and molecular species into these gels. They have both ionic and electronic conduction. The ionic part is defined by proton diffusion and the electronic one by the electron hopping between vanadium ions of different valence states.

In this review the results of a complex study concerning the physical properties of a wide range of vanadium based hydrated compounds such as $\mathrm{H}_{2} \mathrm{~V}_{12-x} \mathrm{Me}_{x} \mathrm{O}_{31 \pm \delta} \cdot n \mathrm{H}_{2} \mathrm{O}(\mathrm{Me}=\mathrm{Mo}, \mathrm{Ti}, \mathrm{Cr}), \mathrm{Me}_{2} \mathrm{~V}_{12} \mathrm{O}_{31 \pm \delta} \cdot n \mathrm{H}_{2} \mathrm{O}(\mathrm{Me}=\mathrm{Li}, \mathrm{Na}, \mathrm{K}, \mathrm{Rb}, \mathrm{Cs})$, and $\mathrm{MeV}_{12} \mathrm{O}_{31 \pm \delta} \cdot n \mathrm{H}_{2} \mathrm{O}(\mathrm{Me}=\mathrm{Mg}, \mathrm{Ca}, \mathrm{Ba})$ are presented.

The basic attention is given to the description of structure, synthesis, electrical properties, and valence conditions of metal ions in the xerogels.
\end{abstract}

Keywords: vanadium oxides, hydrates, physical properties

PACS: 73.25.+I, 81.20.Fw, 82.70.Dg

\section{Introduction}

Transition metal oxides have been intensively studied because of their possible practical applications. Among them the vanadium oxides are important because the atom of vanadium has a non-occupied $3 d$ electronic shell that causes the existance of various vanadium oxides and vanadium-oxygen based compounds. These materials can be separated into four groups: vanadium oxides, substitution and inculcation phases, glasses, and hydrates. The first three groups are studied rather well [1-3]. During the last twenty years the physical chemistry of vanadium hydrates has been developing intensively. From the physical point of view one of the most interesting features of these compounds is their unusually high conductivity in comparison with crystalline, amorphous $\mathrm{V}_{2} \mathrm{O}_{5}$, and glasses on its basis. The results of studies of properties of vanadium hydrates such as structure and chemical composition are summarized in [4-6].

In this paper the review of the last years study of these compounds performed in the Semiconductor Physics Institute (Vilnius, Lithuania) is presented.

\section{Synthesis and structure}

For the first time the preparation method of the hydrated $\mathrm{V}_{2} \mathrm{O}_{5}$ was described by Düllberg [7]. This method was based on the reaction between $\mathrm{Na}_{3} \mathrm{VO}_{4}$ and strong mineral acids. As a result of this reaction the red-brown sediment was produced and identified by Düllberg as the hydrated vanadium pentoxide $\mathrm{V}_{2} \mathrm{O}_{5} \cdot n \mathrm{H}_{2} \mathrm{O}$. Similar method is described in [8] where the vanadium hydrates were produced by interaction between $\mathrm{HCl}$ or $\mathrm{H}_{2} \mathrm{SO}_{4}$ and the solution of $\mathrm{NaVO}_{3}$ or $\mathrm{KVO}_{3}$. However, using these methods one cannot be sure that the produced hydrates do not contain metals $\mathrm{Na}$ or K. This problem was solved by Müller [9]. He suggested two methods. The first of them is the interaction of $\mathrm{V}_{2} \mathrm{O}_{5}$ and hydrogen peroxide and the second one is the fast quenching of the molten $\mathrm{V}_{2} \mathrm{O}_{5}$ into distilled water. Usually these two methods are used until now.

The fibres can be presented as flat tapes of $1000 \AA$ length and $100 \AA$ width [13] (see Fig. 2). As an example we will describe the first preparation method in accordance with [10]. This method is based on the solgel technological process [5]. The vanadium pentoxide powder is dissolved in the hydrogen peroxide at $273 \mathrm{~K}$ because this reaction is exothermic. Then the 


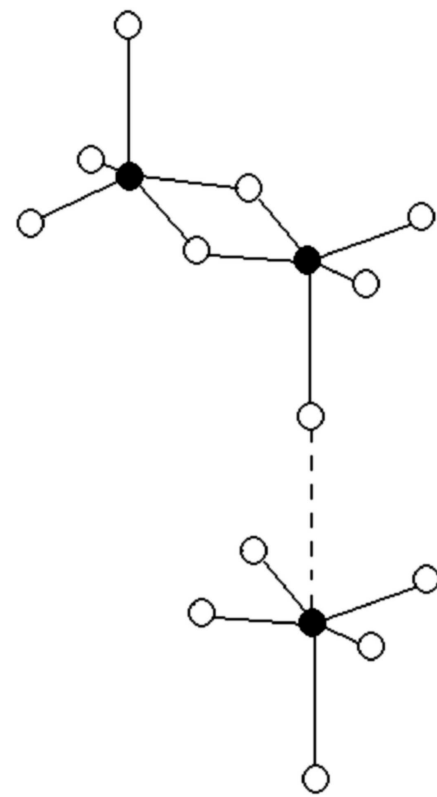

a

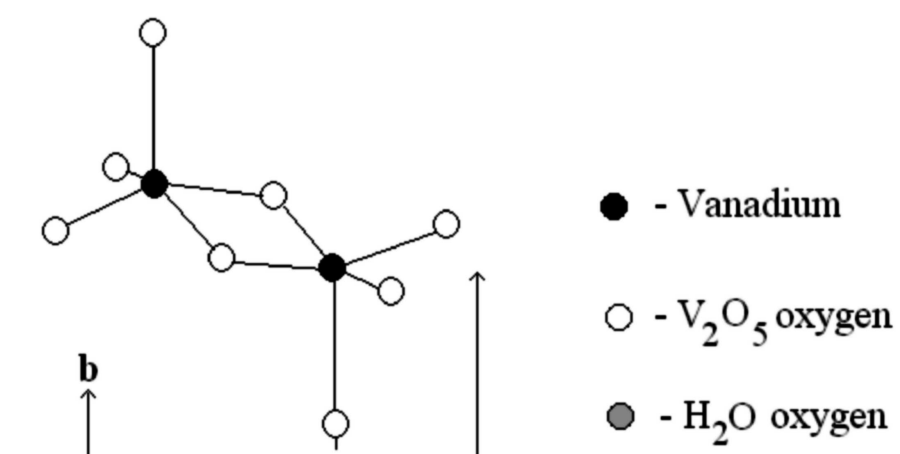

C - - Hydrogen

Fig. 1. Structure of (a) orthorhombic vanadium pentoxide [12] and (b) its xerogel [3].

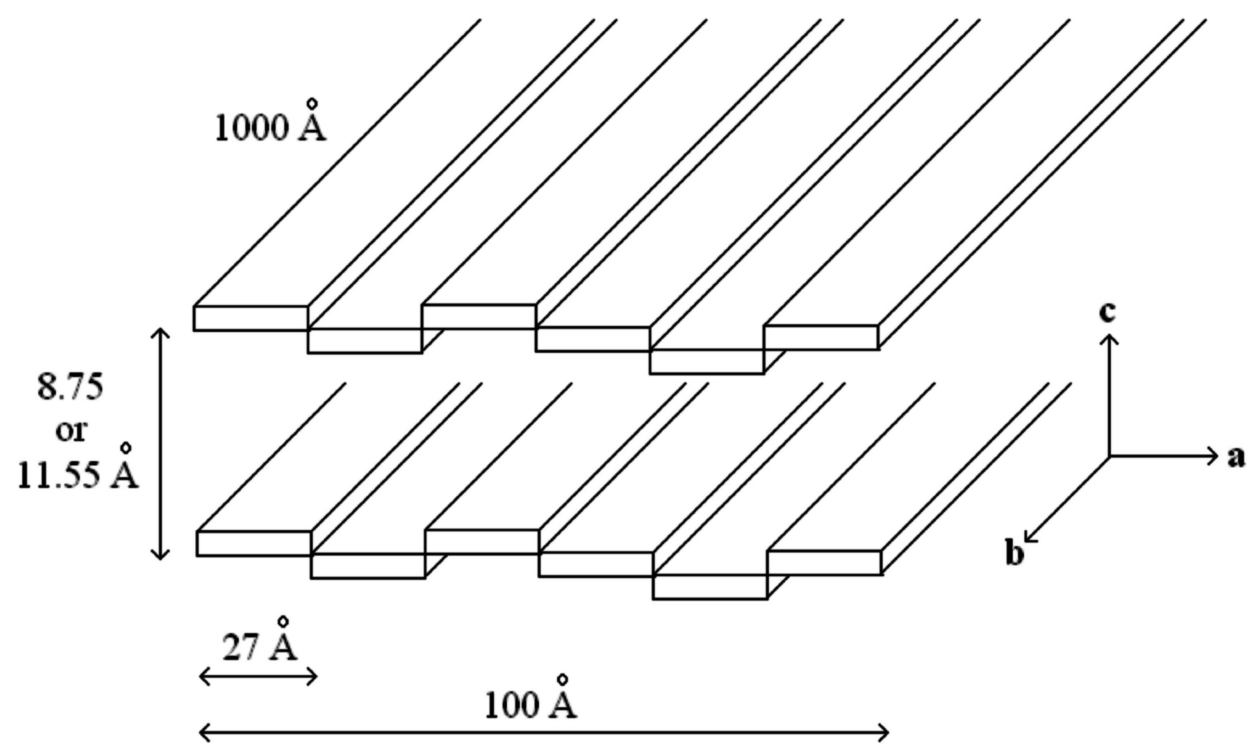

Fig. 2. Structural layers of vanadium pentoxide xerogels [13].

solution is heated at $353 \mathrm{~K}$ for $2 \mathrm{~h}$ for the dissociation of the vanadium peroxide complexes. Obtained gels are deposited on the substrate and baked at room temperature in air. Similar sol-gel technology is used for the preparation of the vanadium hydrates containing various metals and doping elements (see, for example, [10]).

$\mathrm{X}$-ray study of the structure of hydrated $\mathrm{V}_{2} \mathrm{O}_{5}$ was first described in [11]. The structure has a layered character where $\mathrm{V}_{2} \mathrm{O}_{5}$ layers are formed by cross-linked fi- bres separated by water molecules. The structure of these fibres could be related to the $\mathrm{V}-\mathrm{O}$ chains observed in bulk orthorhombic vanadium pentoxide [12] (see Fig. 1). The interlayer distance $c$ depends on the water content in the hydrate. X-ray diffraction, DTA (differential thermal analysis), and GTA (gravimetrical thermal analysis) investigations of gels show that at room temperature the interlayer distance $c=11.55 \AA$ that corresponds to the first phase $\mathrm{V}_{2} \mathrm{O}_{5} \cdot 1.6 \mathrm{H}_{2} \mathrm{O}$ of the hydrate. This phase slowly disappears with tempera- 
ture and at $\sim 393 \mathrm{~K}$ the second $\mathrm{V}_{2} \mathrm{O}_{5} \cdot 0.5 \mathrm{H}_{2} \mathrm{O}$ phase is observed. It presumably corresponds to the removal of weakly bonded water. The interlayer distance $c=$ $8.75 \AA$ in this case. Up to $\sim 573 \mathrm{~K}$ the chemically bonded water is removed from the xerogel and the crystallization of the vanadium pentoxide takes place. So, the dehydration process of the gels may be written as

$$
\mathrm{V}_{2} \mathrm{O}_{5} \cdot 1.6 \mathrm{H}_{2} \mathrm{O} \stackrel{393 \mathrm{~K}}{\longrightarrow} \mathrm{V}_{2} \mathrm{O}_{5} \cdot 0.5 \mathrm{H}_{2} \mathrm{O} \stackrel{573 \mathrm{~K}}{\longrightarrow} \mathrm{V}_{2} \mathrm{O}_{5} \text {. }
$$

A more detailed study of the dehydration by means of IR spectroscopy method shows that the hydrated vanadium gels by nature are polyvanadic acids the chemical formula of which can be written as $\mathrm{H}_{2} \mathrm{~V}_{12} \mathrm{O}_{31} \cdot n \mathrm{H}_{2} \mathrm{O}$ or $\left(\mathrm{H}_{3} \mathrm{O}\right) 2 \mathrm{~V}_{12} \mathrm{O}_{31} \cdot n \mathrm{H}_{2} \mathrm{O}$ [10]. All three formulas $\mathrm{V}_{2} \mathrm{O}_{5} \cdot n \mathrm{H}_{2} \mathrm{O}, \mathrm{H}_{2} \mathrm{~V}_{12} \mathrm{O}_{31} \cdot n \mathrm{H}_{2} \mathrm{O}$, and $\left(\mathrm{H}_{3} \mathrm{O}\right) 2 \mathrm{~V}_{12} \mathrm{O}_{31}$. $n \mathrm{H}_{2} \mathrm{O}$ are used in the literature.

\section{Physical properties}

\subsection{Electrical conductivity}

\subsubsection{General}

One of the features of hydrated vanadium compounds is their unusually high conductivity in comparison with crystalline, amorphous $\mathrm{V}_{2} \mathrm{O}_{5}$ and glasses on its basis. For the first time the semiconducting properties of vanadium pentoxide gels were described in [14]. Now it is established that the conductivity of hydrates consists of two components - electronic and ionic. The electronic part is determined by electron jumps between various valence vanadium ions and the ionic one is due to proton diffusion $[15,16]$. Synthesis and studying of physical properties of various compounds on the basis of vanadium pentoxide gels, performed in the last years, allows describing and understanding in more detail the kinetic phenomena in this class of substances.

Hydrated vanadium compounds are the typical materials obtained by "soft" chemistry methods [5] that allow to prepare the films of various thicknesses in a simple way; $\mathrm{V}-\mathrm{O}$ layers thus are oriented in parallel to the substrate. Electrical conductivity measurements in parallel $\left(\sigma_{=}\right)$and perpendicular $\left(\sigma_{\|}\right)$directions to layers have shown the presence of significant anisotropy. At room temperature $\sigma_{\|}=1.3 \cdot 10^{-3} \mathrm{~S} / \mathrm{m}$ and $\sigma_{=}=$ $44 \mathrm{~S} / \mathrm{m}$, when the reduced vanadium ions content given by the ratio $C=\mathrm{V}^{4+} /\left(\mathrm{V}^{4+}+\mathrm{V}^{5+}\right)\left(\mathrm{V}^{4+}\right.$ and $\mathrm{V}^{5+}$ are the concentrations of $\mathrm{V}^{4+}$ and $\mathrm{V}^{5+}$ ions respectively) is equal to 0.097 [15]. Electrical conductivity of gels increase with $C$, that illustrates Fig. 3 [15]. The general

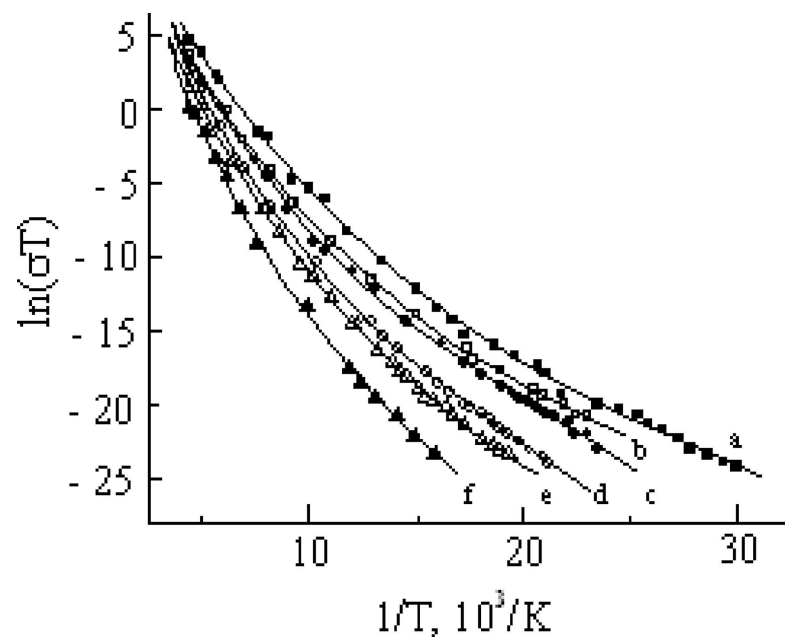

Fig. 3. Electrical conductivity versus temperature for vanadium xerogels containing various reduced vanadium ions content $C: a$ at $0.097, b$ at $0.059, c$ at $0.039, d$ at $0.023, e$ at 0.013 . Curve $f$ was obtained with a polymerized gel $(C=0.005)$ [15].

features for the conductivity dependence on $1 / T$ for all $C$ values are similar: there are low and high temperature ranges (LT and HT respectively), where $\ln (\sigma T)$ varies linearly with $1 / T$, and an intermediate temperature range, where the slope of $\ln (\sigma T)=f(1 / T)$ curve changes continuously. Using the small radius polaron conductivity theory, the activation energy of the conductivity for HT range may be written as

$$
E_{\mathrm{HT}}=\frac{W_{\mathrm{P}}-W_{\mathrm{D}}}{2}-J,
$$

where $W_{\mathrm{P}}$ is the energy of polaron creation, $W_{\mathrm{D}}$ is the so-called Anderson's disorder energy, and $J$ is the transfer integral [17]. From the results presented in Fig. 3, $E_{\mathrm{HT}}=0.35-0.18 \mathrm{eV}$ that practically is equal to the results for amorphous and crystalline $\mathrm{V}_{2} \mathrm{O}_{5}$ [1820]. For the LT range $E_{\mathrm{LT}}=0.043-0.103 \mathrm{eV}$. In this case the activation energy may be written as

$$
E_{\mathrm{LT}}=\frac{W_{\mathrm{D}}}{2}-J
$$

A detailed theoretical treatment has been given by Schnakenberg [21] and the conductivity versus temperature may be written as

$$
\begin{aligned}
\sigma T= & D \nu_{0} \exp \left[-\frac{2 W_{\mathrm{P}}}{h \nu_{0}} \tanh \frac{h \nu_{0}}{4 k T}\right] \\
& \times \exp \left[-\frac{W_{\mathrm{D}} / 2-J}{k T}\right],
\end{aligned}
$$

where $D$ is a constant characteristic of the material and polaron hopping and $\nu_{0}$ is a mean optical phonon frequency. In the Table 1 the values of $E_{\mathrm{HT}}, E_{\mathrm{LT}}$, $W_{\mathrm{P}}, h \nu_{0}$, and $\gamma$ (the constant of the electron-phonon 
Table 1. Values of $E_{\mathrm{HT}}, E_{\mathrm{LT}}, W_{\mathrm{P}}, h \nu_{0}$, and $\gamma$ for various reduction ratios $C$ of the vanadium ions [14].

\begin{tabular}{cccccc}
\hline$C$ & $E_{\mathrm{HT}}, \mathrm{eV}$ & $E_{\mathrm{LT}}, \mathrm{eV}$ & $W_{\mathrm{P}}, \mathrm{eV}$ & $h \nu_{0}, \mathrm{eV}$ & $\gamma$ \\
\hline 0.005 & 0.35 & 0.103 & 0.49 & 0.052 & 9.7 \\
0.013 & 0.25 & 0.069 & 0.37 & 0.035 & 10.4 \\
0.029 & 0.26 & 0.076 & 0.37 & 0.040 & 9.8 \\
0.039 & 0.23 & 0.065 & 0.33 & 0.037 & 8.9 \\
0.059 & 0.22 & 0.050 & 0.34 & 0.034 & 10.0 \\
0.097 & 0.18 & 0.043 & 0.28 & 0.026 & 10.8 \\
\hline
\end{tabular}

coupling) for various reduction ratios $C$ of vanadium ions are presented [14].

\subsubsection{Concentration and mobility of the carriers}

The first data on the carrier concentration in the vanadium pentoxide xerogels have been obtained from the low frequency current fluctuations measurements in the frequency range from $20 \mathrm{~Hz}$ to $10 \mathrm{kHz}$ [22]. The concentration of the carriers was calculated from the empirical formula for the noise such as $f^{-1}$, for which the spectral density of the noise

$$
S(f) \sim \alpha f^{-1},
$$

where $\alpha=2 \cdot 10^{3}$ is the so-called Hooge constant [23]. The calculated values of the concentration are in the range $10^{23}-6 \cdot 10^{24} \mathrm{~m}^{-3}$. However, it is shown that for the hopping conductivity, which takes place in the xerogels, the values of the Hooge constant are close to 1 [24], that allows to speak about a higher concentration of the carriers.

The first data on the concentration and mobility of carriers of a current for vanadium hydrated compounds are presented in [25-27] where from three independent experiments - the measurements of the frequency dependences of the conductivity $(G)$ and capacity $(C)$ of the polyvanadium-molybdenum acid thin films, the investigations of the Cole-Cole diagrams, and the measurements of the time dependences of the transitive currents $I(t)$ - the mobility of carriers along $\left(\mu_{=}\right)$ and across $\left(\mu_{\|}\right)$the $\mathrm{V}-\mathrm{O}$ layers have been determined. The results are summarized in Table 2. The concentrations of carriers are identical for all samples and equal to $(1.2 \pm 0.8) \cdot 10^{25} \mathrm{~m}^{-3}$. In Fig. 4 the temperature dependences of mobility $\mu_{\|}$and concentration $n$ for the $\mathrm{H}_{2} \mathrm{~V}_{10} \mathrm{Cr}_{2} \mathrm{O}_{31.7} \cdot 8.6 \mathrm{H}_{2} \mathrm{O}$ xerogel are shown [26], whence it follows that the concentration practically does not depend on the temperature. In Fig. 5 the temperature dependences of the conductivities across $\left(\sigma_{\|} T\right)$ and along $\left(\sigma_{=} T\right)$ the $\mathrm{V}-\mathrm{O}$ layers are presented [26]. The conductivity activation energies are $\Delta E_{\|}=$ $(0.205 \pm 0.006) \mathrm{eV}$ and $\Delta E_{=}=(0.209 \pm 0.010) \mathrm{eV}$.

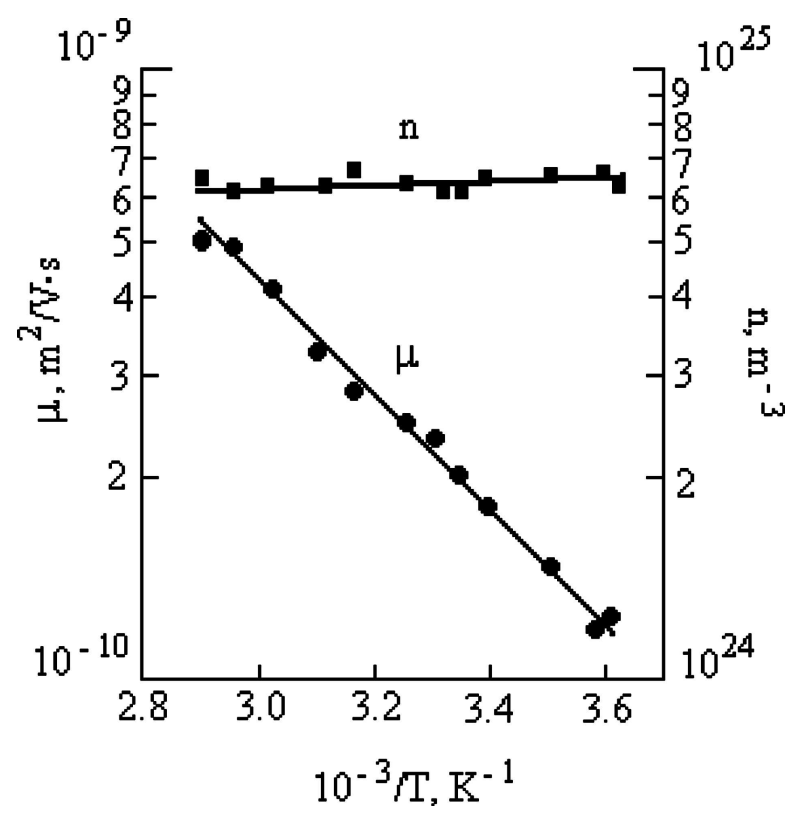

Fig. 4. Carrier mobility and concentration along V-O layers versus temperature for $\mathrm{H}_{2} \mathrm{~V}_{10} \mathrm{Cr}_{2} \mathrm{O}_{31.7} \cdot 8.6 \mathrm{H}_{2} \mathrm{O}$ xerogel [26].

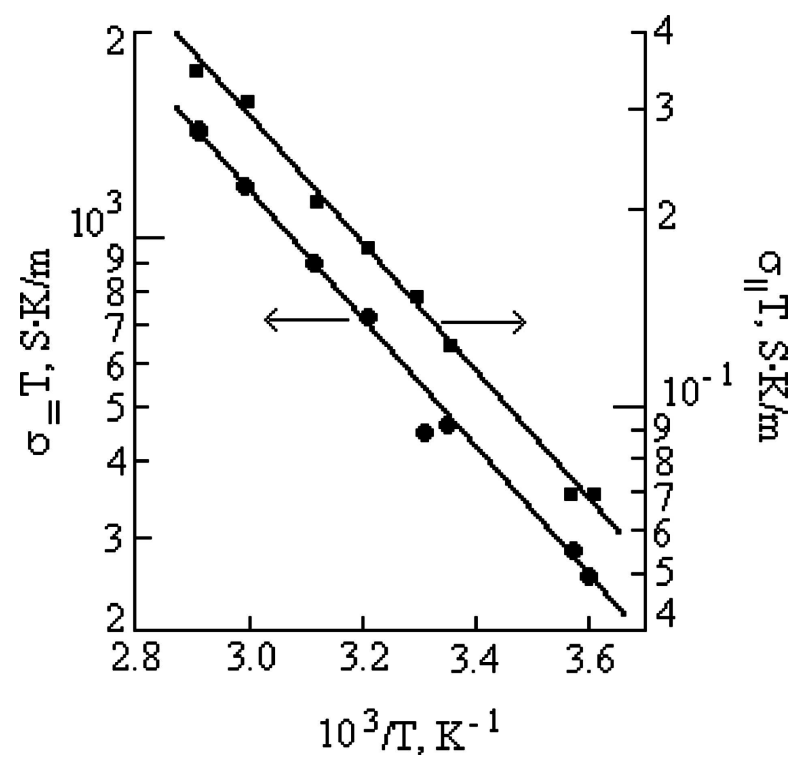

Fig. 5. Temperature dependences of the conductivity across $\left(\sigma_{\|} T\right)$ and along $(\sigma=T)$ the $\mathrm{V}-\mathrm{O}$ layers for $\mathrm{H}_{2} \mathrm{~V}_{10} \mathrm{Cr}_{2} \mathrm{O}_{31.7} \cdot 8.6 \mathrm{H}_{2} \mathrm{O}$ xerogel [26].

The mobility activation energy, determined from Fig. 4, is $\Delta E_{\mu T}=(0.217 \pm 0.008) \mathrm{eV}$. Within the limits of errors the activation energies of the conductivity and mobility are the same. Hence the temperature dependence of conductivity basically is defined by the temperature dependence of mobility. 
Table 2. Carrier mobility in polyvanadium-molybdenum acid xerogels along $\left(\mu_{=}\right)$and across $\left(\mu_{\|}\right)$the V-O layers [25-27].

\begin{tabular}{lcc}
\hline Method of the measurements & \multicolumn{2}{c}{ Mobility, $\mathrm{m}^{2} /(\mathrm{V} \mathrm{s})$} \\
\cline { 2 - 3 } & $\mathrm{H}_{2} \mathrm{~V}_{11.5} \mathrm{Mo}_{0.5} \mathrm{O}_{30.7} \cdot 8.4 \mathrm{H}_{2} \mathrm{O}$ & $\mathrm{H}_{2} \mathrm{~V}_{10} \mathrm{Mo}_{2} \mathrm{O}_{31.7} \cdot 8.6 \mathrm{H}_{2} \mathrm{O}$ \\
\hline$G(f)$ and $C(f)$ measurements & $\mu_{\|}=1.4 \cdot 10^{-12}$ & $\mu_{\|}=2 \cdot 10^{-12}$ \\
Cole-Cole diagrams & $\mu_{\|}=0.9 \cdot 10^{-12}$ \\
$I(t)$ measurements & $\mu_{\|}=1.4 \cdot 10^{-12}, \quad \mu_{=}=0.9 \cdot 10^{-8}$ & \\
\hline
\end{tabular}

\subsubsection{Anisotropy of the conductivity}

From Fig. 5, the anisotropy coefficient, defined as

$$
K=\frac{\sigma_{=}}{\sigma_{\|}},
$$

is equal to $\sim 3.5 \cdot 10^{3}$. As mentioned in 3.1.1, the electronic part of conductivity is defined by the electron jumps between the various valence vanadium ions $[15,16]$. In the polar materials, such as the transitional metals oxides, with the strong electron-phonon coupling, the small radius polarons are formed at temperatures $T>\Theta / 2$, where $\Theta$ is the Debye temperature. For the nonadiabatic case, the probability $P$ for the electrons to jump over the distance $R$ may be written as

$$
P=\nu \exp \left[-2 \alpha R-\frac{W_{\mathrm{P}}-W_{\mathrm{D}}}{2 k T}\right],
$$

where $\nu$ is the frequency of the jumps and $\alpha$ is the decay of the wave function. On the other hand, the hydrated compounds are two-phase systems (electronic and protonic), for which the total resistivity $\rho$ may be written as $[28,29]$

$$
\rho=\rho_{A}^{1-\xi} \rho_{B}^{\xi},
$$

where $\rho_{A}$ and $\rho_{B}$ are the resistivities of the $A$ and $B$ phases respectively (in our case these are the resistivities of the electronic and protonic parts of the conductivity). From (7) and (8), as it has been shown in [30], the conductivity $\sigma_{i}$ of both the single vanadium pentoxide crystals and hydrates in the $i$ direction (the crystallographic directions $a, b$, and $c$ for the single crystals or the direction along and across the $\mathrm{V}-\mathrm{O}$ layers for the hydrates) may be written as

$$
\sigma_{i}=\langle\sigma\rangle R_{i}^{2} \frac{\exp \left[-2 \alpha\left(R_{i}-\langle R\rangle\right)\right]}{\left\langle R_{2}\right\rangle},
$$

where $R_{i}$ is the hopping distance in the $i$ direction, $\langle\sigma\rangle=\left(\sigma_{a} \sigma_{b} \sigma_{c}\right)^{1 / 3}$ for the crystals and $\langle\sigma\rangle=$ $\left(\sigma_{=} \sigma_{=} \sigma_{\|}\right)^{1 / 3}$ for the hydrates ( $\sigma_{=}$and $\sigma_{\|}$are conductivities along and across the $\mathrm{V}-\mathrm{O}$ layers accordingly), $\langle R\rangle=(a+b+c / 2)$, and $\left\langle R_{2}\right\rangle=(a b c / 2)^{2 / 3}$. Figure 6 presents the dependence of the logarithm of reduced conductivity $Y_{i}=\ln \left(\left\langle R_{2}\right\rangle \sigma_{i} /\langle\sigma\rangle R_{i}^{2}\right)$ on the distance

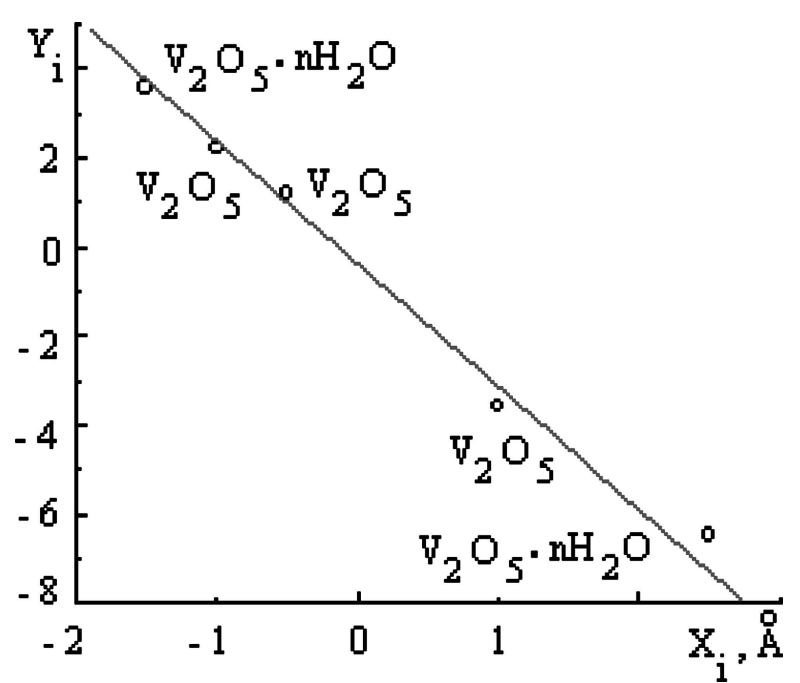

Fig. 6. Logarithm of reduced conductivity $\left(Y_{i}\right)$ dependence on the distances between vanadium ions $\left(X_{i}\right)$ for the xerogels $\mathrm{V}_{2} \mathrm{O}_{5} \cdot n \mathrm{H}_{2} \mathrm{O}$ and oxides $\mathrm{V}_{2} \mathrm{O}_{5}$ [30].

between vanadium ions $X_{i}=R_{i}-\langle R\rangle$ in the $i$ direction [30]. It is clear that as for the single crystals and xerogels the mentioned dependence is exponential in accordance with (9), the anisotropy of the conductivity in both cases can be explained by the anisotropy of the tunnelling term $\exp (-2 \alpha R)$ in the expression (7) for the probability $P$ of the electron jump over the distance $R$.

\subsubsection{Conductivity and phase transitions}

The conductivity dependence on the temperature, which Fig. 1 illustrates, corresponds to the temperature range $23-250 \mathrm{~K}$. The results of the conductivity investigations at the highest temperatures are described in $[31,32]$. It has been shown that for $\mathrm{M}_{2} \mathrm{~V}_{12} \mathrm{O}_{30.7} \cdot n \mathrm{H}_{2} \mathrm{O}$ $(\mathrm{M}=\mathrm{Li}, \mathrm{K}, \mathrm{Na})$ and $\mathrm{MV}_{12} \mathrm{O}_{30.7} \cdot n \mathrm{H}_{2} \mathrm{O}(\mathrm{M}=\mathrm{Mg}, \mathrm{Ca}$, $\mathrm{Sr}, \mathrm{Ba})$ xerogels at the temperature in the interval 332$351 \mathrm{~K}$ the conductivity activation energy changes from $0.26-0.31 \mathrm{eV}$ to $0.57-0.68 \mathrm{eV}$ (see Fig. 7). It can be explained by the partial dehydratation of the samples. More detailed investigation of this phase transition is presented in [33]. As mentioned in 3.1.3, the probability $P$ for the electron to jump over the distance $R$ may be written as formula (7). In the transition metal oxides the wave functions are strongly localized. In 


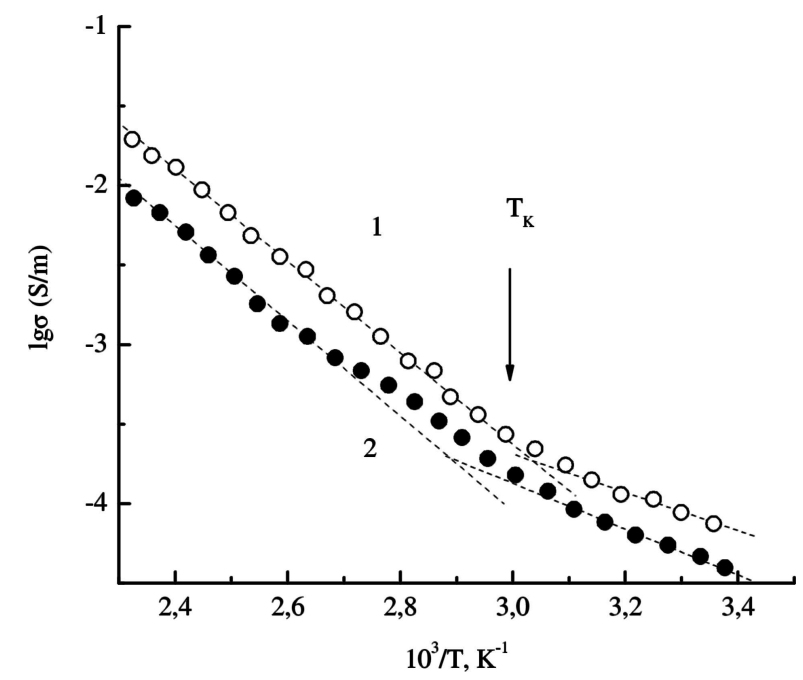

Fig. 7. Average conductivity dependences on the temperature of $\mathrm{M}_{2} \mathrm{~V}_{12} \mathrm{O}_{30.7} \cdot n \mathrm{H}_{2} \mathrm{O}(\mathrm{M}=\mathrm{Li}, \mathrm{K}, \mathrm{Na})$ (curve 1) and $\mathrm{MV}_{12} \mathrm{O}_{30.7} \cdot n \mathrm{H}_{2} \mathrm{O}(\mathrm{M}=\mathrm{Mg}, \mathrm{Ca}, \mathrm{Sr}, \mathrm{Ba})$ (curve 2) xerogels $[31,32]$.

this case the jumps only between the nearest ions are taken into account. It is the so-called autolocalized (A) small polaron case [34]. If the concentration of the defects is less than the critical concentration of the metalinsulator transition, the additional electrons can be occupied and the bonded (B) polarons are formed [34]. The transition between autolocalized and bonded polarons occurs at the critical temperature $T_{\mathrm{K}}$ which can be determined from the equality of the electron jump probabilities (Eq. (7)) for A and B polarons [33]:

$$
T_{\mathrm{K}}=\frac{E_{\mathrm{A}}-E_{\mathrm{B}}}{2 \alpha k R_{i i}\left(C^{-1 / 3}-1\right)},
$$

where $E_{\mathrm{A}}$ and $E_{\mathrm{B}}$ are the activation energies of the conductivity for $\mathrm{A}$ and $\mathrm{B}$ polarons, $R_{i i}$ is the distance between the nearest ions, $\alpha$ is the decay of the wave function, and $C$ is the reduction ratio of vanadium ions. Using the values $T_{\mathrm{K}} \sim 350 \mathrm{~K}, E_{\mathrm{A}} \sim 0.63 \mathrm{eV}, E_{\mathrm{B}} \sim$ $0.29 \mathrm{eV}$ (see Fig. 7), $R_{i i}=2.43 \AA$, and $C=0.07$, from equation (10) one gets $\alpha=1.97 \AA$ that corresponds to the $\alpha$ values for the transition metal oxide [35].

\subsubsection{Conductivity versus humidity}

As mentioned in 3.1.1, the conductivity of hydrates consists of two components - electronic and ionic. The electronic part is determined by electron jumps between various valence vanadium ions and the ionic one is due to proton diffusion, while the ionic conductance depends upon the partial pressure of water [16]. Therefore it is clear that the total conductivity also depends on humidity conditions of the environment. The results of similar investigations are

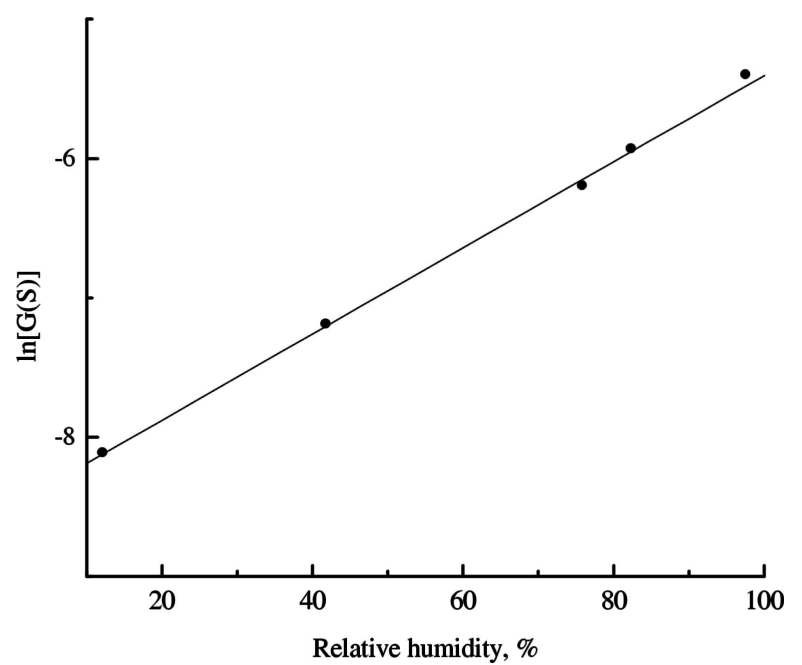

(a)

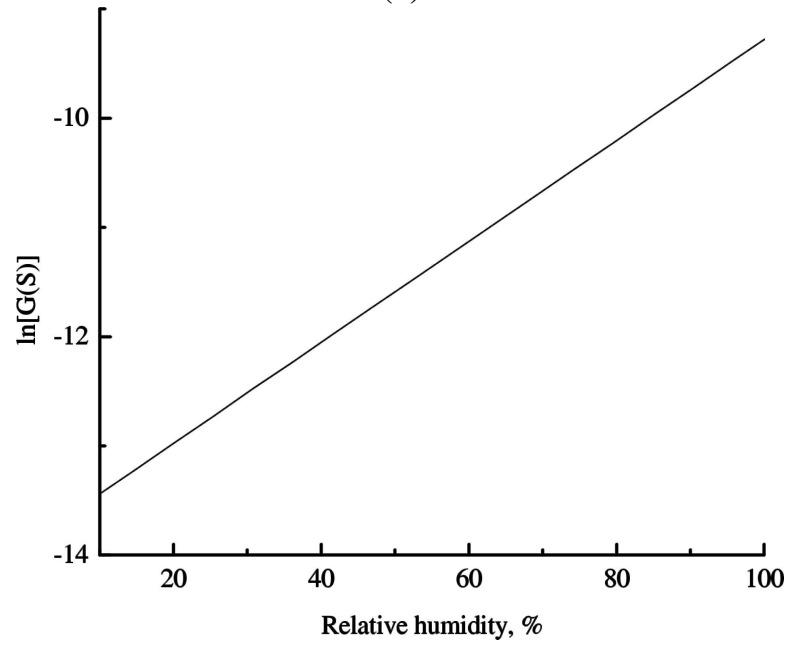

(b)

Fig. 8. Conductance dependences on the relative humidity for (a) $\mathrm{H}_{2} \mathrm{~V}_{11} \mathrm{TiO}_{30.3} \cdot n \mathrm{H}_{2} \mathrm{O}$ and (b) $\mathrm{H}_{2} \mathrm{~V}_{11} \mathrm{MoO}_{31.2} \cdot n \mathrm{H}_{2} \mathrm{O}$ (b) xerogels at $286 \mathrm{~K} \mathrm{[38].}$

described in [36-43]. The dependences of the bulk conductance $G$ on the relative humidity at $286 \mathrm{~K}$ are shown in Fig. 8 for $\mathrm{H}_{2} \mathrm{~V}_{11} \mathrm{TiO}_{30.3} \cdot n \mathrm{H}_{2} \mathrm{O}$ (Fig. 8(a)) and $\mathrm{H}_{2} \mathrm{~V}_{11} \mathrm{MoO}_{31.2} \cdot n \mathrm{H}_{2} \mathrm{O}$ (Fig. 8(b)) [37]. The experimental points of $\ln G=f(\varphi)$ ( $\varphi$ is the relative humidity) were fitted to a linear function

$$
\ln G=a+b \cdot \varphi
$$

where $a=-13.85 \pm 0.08, b=0.045 \pm 0.001$ for $\mathrm{H}_{2} \mathrm{~V}_{11} \mathrm{MoO}_{31.2} \cdot n \mathrm{H}_{2} \mathrm{O}$ and $a=-8.42 \pm 0.21, b=$ $0.031 \pm 0.001$ for $\mathrm{H}_{2} \mathrm{~V}_{11} \mathrm{TiO}_{30.3} \cdot n \mathrm{H}_{2} \mathrm{O}$ xerogels. The sensitivities of the conductance, which are defined as

$$
\beta=\frac{\mathrm{d}[\ln G]}{\mathrm{d} \varphi},
$$

when $T=$ const, are $0.045(\% \mathrm{RH})^{-1}$ for $\mathrm{V}-\mathrm{Mo}$ and $0.031(\% \mathrm{RH})^{-1}$ for V-Ti xerogels [37-42]. 


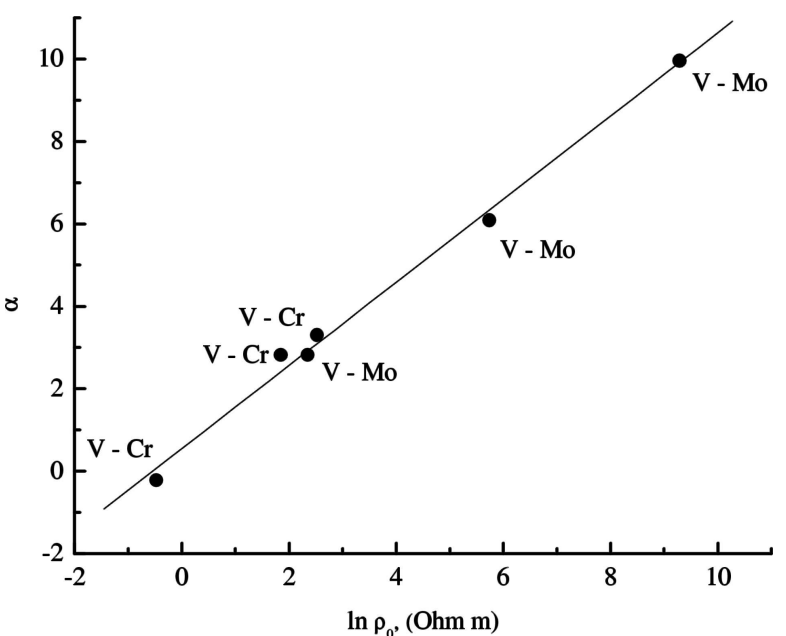

Fig. 9. Sensitivity $\alpha$ dependence on the oxide resistivity $\ln \rho_{\text {ox }}$ [43].

The bulk resistance of vanadium xerogels depends on the relative humidity $\varphi$ as an exponential function [36-43]

$$
\rho=\rho_{0} \exp (-\alpha \varphi),
$$

where $\rho_{0}$ (the resistivity at $\varphi=0$ ) and sensitivity $\alpha$ are constants. Figure 9 shows the dependence of $\alpha$ on $\rho_{0}$ for $\mathrm{H}_{2} \mathrm{~V}_{12-x} \mathrm{Mo}_{x} \mathrm{O}_{31 \pm y} \cdot n \mathrm{H}_{2} \mathrm{O}$ and $\mathrm{H}_{2} \mathrm{~V}_{12-x}$ $\mathrm{Cr}_{x} \mathrm{O}_{31 \pm y} \cdot n \mathrm{H}_{2} \mathrm{O}$ hydrates [43]. As shown in [43], the resistivity $\rho_{0}$ is connected with the electronic $\left(\rho_{\mathrm{e}}\right)$ and protonic $\left(\rho_{\mathrm{p}}\right)$ parts of the total resistivity and then the dependence of sensitivity $\alpha$ on $\rho_{\mathrm{e}}$ and $\rho_{\mathrm{p}}$ may be written as

$$
\alpha=\ln \rho_{\mathrm{e}}-\ln \rho_{\mathrm{p}} .
$$

The electronic and protonic parts of the total conductivity have activation character with some activation energies $\Delta E_{\mathrm{e}}$ and $\Delta E_{\mathrm{p}}$. The activation energy $\Delta E$ of the total conductivity depends on the relative humidity $\varphi$. As shown in [43], this dependence can be expressed through $\Delta E_{\mathrm{e}}$ and $\Delta E_{\mathrm{p}}$ as

$$
\Delta E(\varphi)=\Delta E_{\mathrm{e}}+\varphi\left(\Delta E_{\mathrm{p}}-\Delta E_{\mathrm{e}}\right) .
$$

The values of $\Delta E_{\mathrm{e}}$ and $\Delta E_{\mathrm{p}}$ for the $\mathrm{H}_{2} \mathrm{~V}_{10} \mathrm{Cr}_{2} \mathrm{O}_{31.7}$. $n \mathrm{H}_{2} \mathrm{O}$ are determined in [42] and they are $0.22 \pm$ $0.01 \mathrm{eV}$ and $0.31 \pm 0.02 \mathrm{eV}$ respectively.

\subsubsection{Switching phenomenon}

The experimental results of investigation of the switching phenomenon in thin layers of the vanadium pentoxide based xerogels are presented in $[44,45]$. The typical switching characteristic of $\mathrm{H}_{2} \mathrm{~V}_{12} \mathrm{O}_{30.7} \cdot n \mathrm{H}_{2} \mathrm{O}$ xerogel is shown in Fig. 10 [45]. Upon applying some critical voltage $U_{1}$, named switching voltage, the conductivity of a sample sharply increases, therefore the

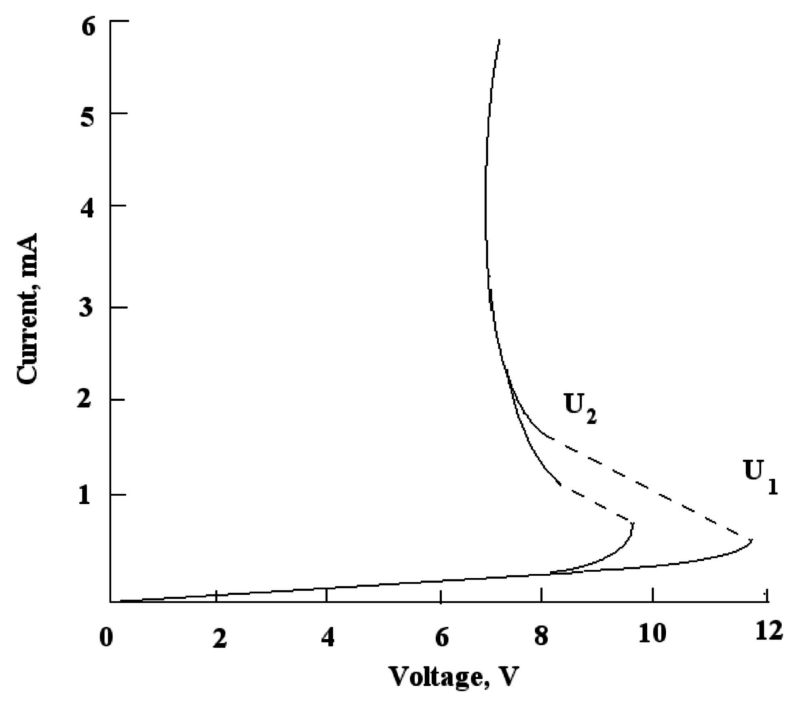

Fig. 10. Switching characteristic of $\mathrm{H}_{2} \mathrm{~V}_{12} \mathrm{O}_{30.7} \cdot n \mathrm{H}_{2} \mathrm{O}$ xerogel after electrical forming [45].

voltage jump decreases down to the value $U_{2}$ and the current through the sample simultaneously grows. It is necessary to note that this characteristic is observed only after a primary forming of the sample by appplying a voltage pulse with a capacity of the order of $0.1 \mathrm{~J}$. Without the primary forming the voltage-current characteristic is linear when the electric field of strength up to $10^{2} \mathrm{~V} / \mathrm{m}$ is applied, and afterwards the deviation from linearity is observed that is caused by the Joule heating. At raising the environment temperature the switching voltage declines and upon achieving the temperature $T>336 \mathrm{~K}$ the phenomenon of switching is not observed. Disappearance of switching at $336 \mathrm{~K}$ allows one to assume that the impurity vanadium dioxide, which is formed as a result of the electrical forming of the sample, is responsible for the switching phenomenon in xerogels [45].

\section{X-ray photoelectron spectra}

Research results of X-ray photoelectron spectra of xerogels are described in [46-54]. It is known that this method allows determining the valence states of ions. It is established that partial dehydration of xerogels, reduction of oxygen, and lower valence metal ions occur after bombardment of the xerogels by argon ions. In Table 3 the results of changes of the concentration and valences depending on the bombardment duration are presented for $\mathrm{M}^{\mathrm{II}} \mathrm{V}_{12} \mathrm{O}_{30.7} \cdot n \mathrm{H}_{2} \mathrm{O}\left(\mathrm{M}^{\mathrm{II}}=\right.$ $\mathrm{Ba}, \mathrm{Sr}, \mathrm{Ca}, \mathrm{Mg}), \mathrm{M}_{2}^{\mathrm{I}} \mathrm{V}_{10} \mathrm{Mo}_{2} \mathrm{O}_{31.7} \cdot n \mathrm{H}_{2} \mathrm{O}\left(\mathrm{M}^{\mathrm{I}}=\mathrm{K}\right.$, $\mathrm{Na}, \mathrm{Li}$ ), and $\mathrm{H}_{2} \mathrm{~V}_{11} \mathrm{TiO}_{30.3} \cdot n \mathrm{H}_{2} \mathrm{O}$ xerogels [49-54]. As follows from the table, after 30 seconds of bombardment, in all compounds alongside with ions of 
Table 3. Changes of concentrations of various ions in xerogels during bombardment by $\mathrm{Ar}^{+}$ions.

\begin{tabular}{lcccccc}
\hline \multirow{2}{*}{ Xerogel } & Ion & \multicolumn{5}{c}{ Duration of bombardment (min.) } \\
\cline { 3 - 7 } & & 0 & 0.5 & 2 & 5 & 10 \\
\hline $\mathrm{M}^{\mathrm{II}} \mathrm{V}_{12} \mathrm{O}_{30.7} \cdot n \mathrm{H}_{2} \mathrm{O}$ & $\mathrm{V}^{5+}$ & 89 at.\% & 57 at.\% & 41 at.\% & 36 at.\% & 35 at.\% \\
& $\mathrm{V}^{4+}$ & 11 at.\% & 40 at.\% & 50 at.\% & 49 at.\% & 50 at.\% \\
& $\mathrm{V}^{3+}$ & 0 at.\% & 3 at.\% & 9 at.\% & 15 at.\% & 15 at.\% \\
\hline $\mathrm{M}_{2}^{\mathrm{I}} \mathrm{V}_{10} \mathrm{Mo}_{2} \mathrm{O}_{31.7} \cdot n \mathrm{H}_{2} \mathrm{O}$ & $\mathrm{V}^{5+}$ & 95 at.\% & 78 at.\% & 61 at.\% & 58 at.\% & 55 at.\% \\
& $\mathrm{V}^{4+}$ & 5 at.\% & 18 at.\% & 32 at.\% & 33 at.\% & 35 at.\% \\
& $\mathrm{V}^{3+}$ & 0 at.\% & 4 at.\% & 7 at.\% & 9 at.\% & 10 at.\% \\
& $\mathrm{Mo}^{6+}$ & 100 at.\% & 95 at.\% & 76 at.\% & 70 at.\% & 67 at.\% \\
& $\mathrm{Mo}^{4+}$ & 0 at.\% & 5 at.\% & 24 at.\% & 30 at.\% & 33 at.\% \\
\hline $\mathrm{H}_{2} \mathrm{~V}_{11} \mathrm{TiO}_{30.3} \cdot n \mathrm{H}_{2} \mathrm{O}$ & $\mathrm{V}^{5+}$ & 86 at.\% & 67 at.\% & 53 at.\% & 38 at.\% & 38 at.\% \\
& $\mathrm{V}^{4+}$ & 14 at.\% & 30 at.\% & 38 at.\% & 48 at.\% & 48 at.\% \\
& $\mathrm{V}^{3+}$ & 0 at.\% & 3 at.\% & 9 at.\% & 14 at.\% & 14 at.\% \\
& $\mathrm{Ti}^{4+}$ & 100 at.\% & 100 at.\% & 100 at.\% & 100 at.\% & 100 at.\% \\
\hline
\end{tabular}

Table 4. Reduction of the oxygen concentration in xerogels after 10 min bombardment by $\mathrm{Ar}^{+}$ions.

\begin{tabular}{cc}
\hline Xerogel & $-\Delta \mathrm{O}, \%$ \\
\hline $\mathrm{M}^{\mathrm{II}} \mathrm{V}_{12} \mathrm{O}_{30.7} \cdot n \mathrm{H}_{2} \mathrm{O}$ & 13 \\
$\mathrm{M}_{2}^{\mathrm{I}} \mathrm{V}_{10} \mathrm{Mo}_{2} \mathrm{O}_{31.7} \cdot n \mathrm{H}_{2} \mathrm{O}$ & 22 \\
$\mathrm{H}_{2} \mathrm{~V}_{11} \mathrm{TiO}_{30.3} \cdot n \mathrm{H}_{2} \mathrm{O}$ & 24 \\
\hline
\end{tabular}

vanadium of valence four and five the $\mathrm{V}^{3+}$ or $\mathrm{V}^{4+}$ ions are formed alongside with molybdenum of valence six. Thus their concentration increases with duration of bombardment and after 10 minutes tends to saturation. It is accompanied by a reduction of oxygen in the samples that is presented in Table 4. From Table 3 the reduction ratio of xerogels concentration $C=C_{\mathrm{v}^{4+}} /\left(C_{\mathrm{v}^{4+}}+C_{\mathrm{v}^{5+}}\right)$ at the moment of time $t=$ 0 is equal to 0.05 for $\mathrm{M}_{2}^{\mathrm{I}} \mathrm{V}_{10} \mathrm{Mo}_{2} \mathrm{O}_{31.7} \cdot n \mathrm{H}_{2} \mathrm{O}$, to 0.11 for $\mathrm{M}^{\mathrm{II}} \mathrm{V}_{12} \mathrm{O}_{30.7} \cdot n \mathrm{H}_{2} \mathrm{O}$, and to 0.14 for $\mathrm{H}_{2} \mathrm{~V}_{11} \mathrm{TiO}_{30.3}$. $n \mathrm{H}_{2} \mathrm{O}$ xerogels. This should support that the conductivity of the specified groups of compounds should increase with the growth of quantity $C$, and that appears to be a true result [55]. From all the investigated xerogels on the basis of vanadium pentoxide the greatest reduction ratio $C_{\mathrm{v}^{4+}} /\left(C_{\mathrm{v}^{4+}}+C_{\mathrm{v}^{5+}}\right)=0.24$ and consequently also the greatest conductivity possess the hydrates of $\mathrm{V}_{2} \mathrm{O}_{5}$ containing up to 9.5 mole $\%$ of $\mathrm{GeO}_{2}$ [56].

\section{Conclusions}

The gels on the basis of polyvanadic acids possess unique physical properties which are possible to adjust over a wide range that allows one to find for them lots of applications in various areas of technology. On the basis of vanadium oxide gels the $\mathrm{TTF}_{x} \mathrm{~V}_{2} \mathrm{O}_{5}$ and $\mathrm{Bz}_{x^{-}}$ $\mathrm{V}_{2} \mathrm{O}_{5}$ ( $\mathrm{Bz}$ is benzidine, $x \geq 1$ ) compounds are pro- duced, which are the first molecular bronzes of transitional metal oxides [57]. The electric conductivity of the last one at room temperature equals $2.8 \cdot 10^{8} \mathrm{~S} / \mathrm{m}$. Moreover, nanotubes on the basis of vanadium pentoxide have been synthesized rather recently by using the sol-gel technology [58-60].

\section{References}

[1] A.A. Bugayev, B.P. Zakhartchenya, and F.A. Tchudnovskiy, Metal-Insulator Phase Transition and its Application (Nauka, Leningrad, 1979) [in Russian].

[2] A.A. Fotiev, V.L. Volkov, and V.K. Kapustkin, Vanadium Oxide Bronzes (Nauka, Moscow, 1978) [in Russian].

[3] V.L. Volkov, Inculcation Phases Based on Vanadium Oxides (Ural Scientific Centre of USSR Academy of Sciences, Sverdlovsk, 1987) [in Russian].

[4] P.N. Pletnyov, A.A. Ivakin, D.G. Klestchyov, and T.A. Burmistrova, Hydrated Oxides of IV and V Group (Nauka, Moscow, 1986) [in Russian].

[5] J. Livage, Synthesis of polyoxovanadates via "chimie douce", Coord. Chem. Rev. 178-180(2), 999-1018 (1998).

[6] J. Livage and D. Ganguli, Sol-gel electrochromic coating and devices: A review, Solar Energy Mater. Solar Cells 68(3-4), 365-381 (2001).

[7] P. Düllberg, Über das Verhalten der Vanadate in wässeriger Lösung, Z. Phys. Chem. 45(2), 129-181 (1903).

[8] A.B. Berkutov, A.K. Iliasova, and R.A. Geskina, About hydrated vanadium pentoxide, Zh. Neorg. Khim. [J. Inorg. Chem. (USSR)] 7(9), 2134-2139 (1962).

[9] E. Müller, Herstellung kolloider Vanadinsaüre nach einer neuen Dispersionsmethode, Z. Chem. Ind. Kolloide 8(2), 302-303 (1911). 
[10] V.L. Volkov, G.S. Zakharova, and V.M. Bondarenka, Simple and Complicated Xerogels of Polyvanadates (Ural Branch of Russian Academy of Sciences, Yekaterinburg, 2001) [in Russian].

[11] P. Aldebert, N. Baffier, N. Gharbi, and J. Livage, Layered structure of vanadium pentoxide gels, Mater. Res. Bull. 16(6), 669-676 (1981).

[12] H.G. Bachman, F.R. Achmed, and W.H. Barnes, Über Structure von $\mathrm{V}_{2} \mathrm{O}_{5}$, Z. Kristallogr. 115(1), 110-131 (1961).

[13] J.-J. Legendre and J. Livage, Vanadium pentoxide xerogels. I. Structural study by electron diffraction, J. Colloid Interface Sci. 94(1), 75-83 (1983).

[14] J. Bullot, O. Gallais, M. Gauthier, and J. Livage, Semiconducting properties of amorphous $\mathrm{V}_{2} \mathrm{O}_{5}$ layers deposited from gels, Appl. Phys. Lett. 36(12), 986-988 (1980).

[15] J. Bullot, P. Cordier, O. Gallais, M. Gauthier, and J. Livage, Thin layers deposited from $\mathrm{V}_{2} \mathrm{O}_{5}$ gels. I. A conductivity study, J. Non-Cryst. Solids 68(1), 123-134 (1984).

[16] P. Barboux, N. Baffier, R. Morineau, and J. Livage, Diffusion protonique dans les xerogels de pentoxyde de vanadium, Solid State Ionics 9-10(2), 1073-1080 (1983).

[17] N.F. Mott and E.A. Davis, Electronic Processes in Non-crystalline Materials (Clarendon Press, Oxford, 1971).

[18] V.A. Ioffe and I.B. Patrina, Comparison of the smallpolaron theory with the experimental data of current transport in $\mathrm{V}_{2} \mathrm{O}_{5}$, Phys. Status Solidi 40(1), 389-395 (1970).

[19] A.R. Tourky, Z. Hanafi, and K. Al Zewel, The colour problem of vanadium pentoxide, Z. Phys. Chem. 242(5/6), 305-311 (1969).

[20] T. Allersma, R. Hakim, T.N. Kennedy, and J.D. Mackenzie, Structure and physical properties of solod and liquid vanadium pentoxide, J. Chem. Phys. 46(1), 154-160 (1967).

[21] J. Schnakenberg, Polaronic impurity hopping conduction, Phys. Status Solidi A 28(2), 623-633 (1968).

[22] L.B. Kiss, K. Bali, T. Szörenyi, and I. Hevesi, Noise measurements on thin films deposited from vanadium pentoxide gels, Solid State Commun. 58(9), 609-611 (1986).

[23] F. Hooge, $1 / f$ noise, Physica B 83(1), 14-23 (1976).

[24] B.I. Shklovskii, Theory of $1 / f$ noise for hopping conduction, Solid State Commun. 33(3), 273-276 (1980).

[25] V. Bondarenka, S. Grebinskij, S. Mickevičius, V. Volkov, and G. Zakharova, Mobility and concentration of charge carriers in $\mathrm{H}_{2} \mathrm{~V}_{12-x} \mathrm{Mo}_{x} \mathrm{O}_{31 \pm y} \cdot n \mathrm{H}_{2} \mathrm{O}$ xerogels, Lithuanian J. Phys. 36(2), 131-139 (1996).

[26] V. Bondarenka, S. Grebinskij, S. Mickevičius, V. Volkov, and G. Zakharova, Temperature dependences of charge carrier mobility and concentration in
$\mathrm{H}_{2} \mathrm{~V}_{10} \mathrm{Cr}_{2} \mathrm{O}_{31.7} \cdot 8.6 \mathrm{H}_{2} \mathrm{O}$ xerogels, Lithuanian J. Phys. 37(5), 411-415 (1997).

[27] V. Bondarenka, S. Grebinskij, S. Mickevicius, V. Volkov, and G. Zakharova, Physical properties of the polyvanadium-molybdenum acid xerogels, J. NonCryst. Solids 226(1), 1-10 (1998).

[28] S.H. Tao, W. Ming-Tang, L. Ping, and Y. Xi, Porosity control of humidity-sensitive ceramics and theoretical model of humidity-sensitive characteristics, Sensors Actuators 19(1), 61-70 (1989).

[29] D.S. McLachlan, Equations for the conductivity of macroscopic mixtures, J. Phys. C 19(9), 1339-1354 (1986).

[30] S. Grebinskij, V. Bondarenka, and S. Mickevicius, Anisotropy of the conductivity in $\mathrm{V}_{2} \mathrm{O}_{5}$ single crystals and layered films deposited from gels, in: Abstracts of the International Conference on "Mass and Charge Transport in Inorganic Materials", Jesolo Lido, Italy, p. 26 (2000).

[31] V. Volkov, V. Bondarenka, G. Zakharova, R. Bareikiene, N. Grebenschikova, and L. Perelyaeva, Electrical conductivity and IR spectra of $\mathrm{M}_{2}^{\mathrm{I}}\left(\mathrm{M}^{\mathrm{II}}\right) \mathrm{V}_{12} \mathrm{O}_{30.7} \cdot n \mathrm{H}_{2} \mathrm{O}$, Izv. Akad. Nauk SSSR, Neorg. Mater. [Inorg. Mater. (USSR)] 23(1), 135-138 (1987).

[32] V. Volkov, V. Bondarenka, G. Zakharova, R. Bareikiene, and A. Ivakin, Electrical conductivity of $\mathrm{H}_{2} \mathrm{~V}_{12-x} \mathrm{Mo}_{x} \mathrm{O}_{31 \pm y} \cdot n \mathrm{H}_{2} \mathrm{O}$ xerogels, Izv. Akad. Nauk SSSR, Neorg. Mater. [Inorg. Mater. (USSR)] 23(1), 139-141 (1987).

[33] S. Grebinskij, V. Bondarenka, and S. Mickevicius, Transport phenomena in layered vanadium pentoxide xerogels, in: Abstracts of the International Conference on "Mass and Charge Transport in Inorganic Materials", Jesolo Lido, Italy, p. 25 (2000).

[34] N.F. Mott and R.W. Gurney, Electronic Processes in Ionic Crystals (Clarendon Press, Oxford, 1940).

[35] L. Murawski, C.H. Chung, and J.D. Mackenzie, Electrical properties of semiconducting oxide glasses, J. Non-Cryst. Solids 32(1) 91-104 (1979).

[36] V. Bondarenka, S. Grebinskij, S. Mickevicius, V. Volkov, and G. Zakharova, Physical properties of the polyvanadium-molybdenum acid xerogels, J. NonCryst. Solids 226(1), 1-10 (1998).

[37] V. Bondarenka, S. Grebinskij, S. Mickevicius, V. Volkov, and G. Zakharova, Thin films of polyvanadium-molybdenum acid as starting materials for humidity sensors, Sensors Actuators B 28(3), 227-231 (1995).

[38] V. Bondarenka, S. Grebinskij, S. Mickevicius, V. Volkov, and G. Zakharova, The dependence of the electrical properties of the polyvandium-molybdenum acid on the frequency and humidity, Fiz. Tverd. Tela [Phys. Solid State (St. Petersburg)] 37(5), 1429-1437 (1995). 
[39] V. Bondarenka, S. Grebinskij, S. Mickevicius, H. Tvardauskas, Z. Martunas, V. Volkov, and G. Zakharova, Conductance versus humidity of vanadium-metaloxygen layers deposited from gels, Phys. Status Solidi A 169(2), 289-294 (1998).

[40] V. Bondarenka, S. Grebinskij, S. Mickevicius, H. Tvardauskas, Z. Martunas, V. Volkov, and G. Zakharova, Humidity sensors based on $\mathrm{H}_{2} \mathrm{~V}_{11} \mathrm{TiO}_{30.3} \cdot n \mathrm{H}_{2} \mathrm{O}$ xerogels, Sensors Actuators B 55(1), 60-64 (1999).

[41] V. Bondarenka, S. Grebinskij, S. Mickevicius, H. Tvardauskas, Z. Martunas, V. Volkov, and G. Zakharova, Humidity sensors based on vanadium-metal-oxygen layers deposited from gels, in: Proceedings of BEC'98, "The 6th Biennial Conference on Electronics and Microsystem Technology", Tallin, Estonia, pp. 247-250 (1998).

[42] V. Bondarenka, S. Grebinskij, S. Mickevicius, V. Volkov, and G. Zakharova, Humidity sensing properties of $\mathrm{V}_{2} \mathrm{O}_{5}$ based xerogels, in: Proceedings of the Conference "SeSens 2000", Veldhoven, the Netherlands, pp. 665-668 (2000).

[43] V. Bondarenka, S. Grebinskij, S. Mickevičius, V. Volkov, and G. Zakharova, Electrical conductivity of vanadium pentoxide xerogels, Lithuanian J. Phys. 42(6), 435-439 (2002).

[44] J. Bulot, O. Gallais, M. Gauthier, and J. Livage, Threshold switching in $\mathrm{V}_{2} \mathrm{O}_{5}$ layers deposited from gels, Phys. Status Solidi A 71(1), K1-K4 (1982).

[45] V. Bondarenka, S. Grebinskij, and S. Mickevičius, Switching in layered vanadium pentaoxide xerogels, Lithuanian J. Phys. 35(1), 72-75 (1995).

[46] V. Bondarenka, S. Grebinskij, S. Mickevicius, H. Tvardauskas, and S. Kaciulis, Determination of vanadium valence states in hydrated compounds, J. Alloys Compounds 382(1-2), 239-243 (2004).

[47] V. Bondarenka, S. Grebinskij, Z. Martūnas, S. Mickevičius, H. Tvardauskas, S. Kačiulis, L. Pandolfi, V. Volkov, and N. Podvalnaia, Sol-gel synthesis and XPS characterization of vanadium oxide bronzes, Lithuanian J. Phys. 46(2), 185-190 (2006).

[48] V. Bondarenka, V. Volkov, G. Zakharova, S. Kačiulis, and A. Plešanovas, X-ray photoelectron spectroscopy of the polyvanadium acid, Lithuanian J. Phys. 33(2), 71-73 (1993).

[49] V. Bondarenka, S. Kaciulis, A. Pleshanovas, V. Volkov, and G. Zakharova, Photoelectron spectroscopy of polyvanadium-molybdenum acid, Appl. Surf. Sci. 78(2), 107-112 (1994).
[50] V. Bondarenka, H. Tvardauskas, Z. Martūnas, S. Grebinskij, S. Mickevičius, V. Volkov, and G. Zakharova, X-ray photoelectron spectroscopy of $\mathrm{BaV}_{12} \mathrm{O}_{30.7} \cdot 8.2 \mathrm{H}_{2} \mathrm{O}$ xerogels, Lithuanian J. Phys. 36(5), 422-427 (1996).

[51] V. Bondarenka, H. Tvardauskas, Z. Martūnas, S. Grebinskij, S. Mickevičius, V. Volkov, and G. Zakharova, X-ray photoelectron and Auger spectra of $\mathrm{Li}_{2} \mathrm{~V}_{10} \mathrm{Mo}_{2} \mathrm{O}_{31.6} \cdot 10.6 \mathrm{H}_{2} \mathrm{O}$ xerogels, Lithuanian J. Phys. 37(5), 440-445 (1997).

[52] H. Tvardauskas, V. Bondarenka, Z. Martunas, S. Grebinskij, S. Mickevicius, V. Volkov, and G. Zakharova, Photoelectron spectroscopy of $\mathrm{MV}_{12} \mathrm{O}_{30.7} \cdot n \mathrm{H}_{2} \mathrm{O}$ xerogels $(\mathrm{M}=\mathrm{Mg}, \mathrm{Ca}, \mathrm{Sr}, \mathrm{Ba})$, Appl. Surf. Sci. 134(2), 229-233 (1998).

[53] V. Bondarenka, H. Tvardauskas, Z. Martūnas, S. Grebinskij, S. Mickevičius, V. Volkov, and G. Zakharova, X-ray photoelectron spectroscopy of the polyvanadium-titanium acid, Lithuanian J. Phys. 38(2), 191-195 (1998).

[54] V. Bondarenka, H. Tvardauskas, Z. Martūnas, S. Grebinskij, S. Mickevičius, V. Volkov, and G. Zakharova, Influence of ion bombardment on the metal ion states in $\mathrm{Li}_{2} \mathrm{~V}_{10} \mathrm{Mo}_{2} \mathrm{O}_{31.6} \cdot 10.6 \mathrm{H}_{2} \mathrm{O}$ surface, Lithuanian J. Phys. 38(3), 307-312 (1998).

[55] H. Yagi and T. Saiki, Humidity sensor using NASICON not containing phosphorus, Sensors Actuators B 5(1), 135-138 (1991).

[56] H. Hirashima and K. Sudo, Structure and physical properties of $\mathrm{V}_{2} \mathrm{O}_{5}$ gels containing $\mathrm{GeO}_{2}$, J. NonCryst. Solids 121(1-3), 68-71 (1990).

[57] H. Masbal, D. Tinet, and M. Crespin, A molecular bronze formed by intercalation of benzidine in $\mathrm{V}_{2} \mathrm{O}_{5}$ gels, J. Chem. Soc. Chem. Commun. 14, 935-936 (1985).

[58] M.E. Spahr, P. Bitterli, R. Nesper, M. Muller, F. Krumeich, and H.U. Nissen, Redox-active nanotubes of vanadium oxide, Angewandte Chemie Int. Ed. 37(9), 1263-1265 (1998).

[59] F. Krumeich, H.-J. Muhr, M. Niederberger, F. Bieri, B. Schnyder, and R. Nesper, Morphology and topochemical reactions of novel vanadium oxide nanotubes, J. Am. Chem. Soc. 121(36), 8324-8331 (1999).

[60] J.M. Reinoso, H.-J. Muhr, F. Krumeich, F. Bieri, and R. Nesper, Controlled uptake and release of metal cations by vanadium oxide nanotubes, Helv. Chim. Acta 83(8), 1673-2053 (2000). 


\title{
HIDRATUOTŲ VANADŽIO JUNGINIŲ ELEKTRINĖS SAVYBĖS
}

\author{
V. Bondarenka, A. Pašiškevičius
}

Puslaidininkiu fizikos institutas, Vilnius, Lietuva

\section{Santrauka}

Vanadžio pentoksido geliai turi sluoksniuotą sandarą, kur V-O sluoksniai atskirti vandens molekulemis. Tai leidžia įterpti tarp sluoksnių ìvairius jonus bei molekules. Elektrinis gelių laidumas turi du sandus - elektroninị, atsirandantị dèl elektronų šuolių tarp ivvairiavalenčiu jonų, ir protoninį, kurị lemia protonų difuzija.
Pateikti hidratuotu vanadžio junginių, tokių kaip $\mathrm{H}_{2} \mathrm{~V}_{12-x} \mathrm{Me}_{x} \mathrm{O}_{31 \pm \delta} \cdot n \mathrm{H}_{2} \mathrm{O}(\mathrm{Me}=\mathrm{Mo}, \mathrm{Ti}, \mathrm{Cr}), \mathrm{Me}_{2} \mathrm{~V}_{12} \mathrm{O}_{31 \pm \delta}$. $n \mathrm{H}_{2} \mathrm{O}(\mathrm{Me}=\mathrm{Li}, \mathrm{Na}, \mathrm{K}, \mathrm{Rb}, \mathrm{Cs})$ ir $\mathrm{MeV}_{12} \mathrm{O}_{31 \pm \delta} \cdot n \mathrm{H}_{2} \mathrm{O}(\mathrm{Me}=$ $\mathrm{Mg}, \mathrm{Ca}, \mathrm{Ba})$, kompleksinių tyrimų rezultatai.

Pagrindinis dèmesys skirtas hidratų sandaros, sintezès, elektrinių savybių ypatybėms ir metalų jonų valentingumui. 